\title{
A Study on the Construction of Multi-modal Campus Culture Targeting ASEAN Students
}

\author{
In Perspective of Guangxi Normal University*
}

\author{
Lili Li \\ College of International Culture and Education \\ Guangxi Normal University \\ Guangxi, P.R. China
}

\begin{abstract}
In the process of promoting the educational internationalization, the education and campus culture construction of Guangxi Normal University targeting ASEAN students has become an icon in the cultural and educational exchange of Guangxi and ASEAN, having attracted close attention from home and abroad. This study will make a review and analysis of the achievements made by Guangxi Normal University in the construction of campus culture targeting ASEAN students in recent years, and make a theoretical summary of the practice with the multi-modal classification concept.
\end{abstract}

Keywords-international students from ASEAN; campus culture; multi-modality; Guangxi Normal University

\section{INTRODUCTION}

Guangxi Normal University is one of the first 8 institutions of higher learning approved by the Chinese government to recruit international students. The central government's positioning on the enrollment of overseas students from Guangxi Normal University is taking advantage of geographical and network superiority, and mainly recruiting international students from ASEAN.

Guangxi Normal University has established close and long-term cooperative relationship with more than 100 ASEAN universities and educational institutions. It is the scholarship recipient institution concerning the following scholarships, i.e, Chinese Government Scholarship, Confucius Institute Scholarship, the Guangxi ASEAN National Student Scholarship and some ASEAN National Government Scholarship students. It is also one of the first Ministry of Education approved demonstration base for studying in China and Overseas Chinese Affairs Office approved education base for Chinese language education.

Guangxi Normal University is actively cooperating with ASEAN countries, and receives more than 1000 ASEAN teachers and students in various training, language and cultural exchange activities each year. The university has also built three Confucius Institutes in the ASEAN region

* This study is supported by the National Social Science Foundation of China (Grant No.14BYY043)
(Thailand, Vietnam and Indonesia), and actively carries out cultural and educational exchanges and cooperation between China and ASEAN countries with the support of Confucius Institutes. In the past ten years, schools have trained about 10000 graduates for ASEAN countries. They have become the backbone of all walks of life in ASEAN countries. [1]

In addition to running schools and training, Guangxi Normal University has a specific consideration for ASEAN Students in many aspects of facilities allocation, cultural activities, research activities, base and center construction, and the university has indeed built up the cultural homeland for the ASEAN students.

In the process of promoting the internationalization of education, Guangxi Normal University's education for the ASEAN students and the construction of the campus culture has become an icon of Guangxi's ASEAN cultural cooperation and exchanges, which has attracted close attention from home and abroad.

This study will sort out and analyze the achievements made by Guangxi Normal University in recent years in the aspect of the constructing campus culture targeting ASEAN overseas students, and make a theoretical summary of the practice is this respect with a multi-modal classification concepts.

\section{CONCEPTUAL DEFINITION}

Campus culture is a specific cultural phenomenon accompanied by school education. However, academic research on campus culture is later than the study of school education. The concept of campus culture was proposed in the 1990s. In the 1950s, the campus culture gradually became one of the research hot spots, and received a wide range of research concerns. In the mid to late 1980s, as Xiaoyan Jia put it, "The campus culture became an independent cultural form among social cultures". [2] ${ }^{\mathrm{p} 3}$

Heqiu Deng, a Chinese scholar, reviewed the literature on campus culture and believed that because of the broad and narrow understandings of the concept of "culture", academic understanding of the concept of "campus culture" can be broadly classified into the following ten main 
viewpoints: i. extra-curricular activities; ii. campus spirit; iii. cultural atmosphere; iv. ideological theory; v. material and spiritual totalism; vi. compound theory of cultural elements; vii, the cultural directive theory; viii. the enlightenment theory; viiii, the elite theory; $x$. activities [3] ${ }^{\text {p2-3 }}$.

The above-cited concepts can be divided into two groups. One group thinks that campus culture contains multiple contents of campus life, concerning material, system and spiritual aspects, whose subjects can be students, teachers, managers, workers, etc. The other group deems that campus culture refers to the student culture within the school, and is mainly based on the student's leisure life, which is mainly reflected in the students' community activities.

According to the understanding of the concept of "campus culture" in the academic world, this study identifies the concept of Heqiu Deng, Campus culture is the sum of the school spirit and the cultural environment needed to cultivate the spirit of the school in the long-term development of the school. [3] ${ }^{\mathrm{p} 3}$ It is a complex of factors such as value concept, behavior mode, school style, campus spirit, moral standard, development goal, ideological consciousness, material construction and so on, which are formed by the school in the long-term development.

In view of the comprehensiveness and complexity of the concept of "campus culture," the form of campus culture construction has also presented a variety of modes. This article will analyze the practice of building the campus culture of ASEAN students at Guangxi Normal University from a multimodal perspective.

\section{Multimodal CONSTRUCTION OF CAMPUS CULTURE TARGETING INTERNATIONAL STUDENTS FROM ASEAN}

The construction of the campus culture targeting ASEAN students in Guangxi Normal University is very effective in the sense that it is constructed from a multi-dimensional perspective.

The practice of campus culture construction covers the six aspects that follow: teaching; management; campus construction; cultural activities; scientific research and discipline construction. The scope of its radiation is generally overlapped with the material, spiritual and institutional aspects of culture.

\section{A. Mode 1: Teaching Platforms Targeting ASEAN Students}

There are 21 currently-established teaching colleges and departments in Guangxi Normal University, which offers 78 full-time undergraduate majors, 27 master's degreeauthorized first-level disciplines, 19 professional master's degree delegations, 6 doctoral-degree first-level disciplines, and post-doctoral scientific research flow. There are 3 stations and 35 Key Disciplines for Guangxi Institutions of Higher Learning). The disciplines cover 12 major categories except military science. The liberal arts disciplines, doctoral programs, master programs, and autonomous regional liberal arts majors all rank among the top universities in Guangxi.

The students of Guangxi Normal University are mainly from ASEAN countries, especially those from Thailand,
Vietnam, and Indonesia. The proportion of such students is not only reflected in the long-term students, but also reflected in short-term language training and cultural studies.

The predecessor of the Chinese Language and Culture Department of the College of International Culture and Education is the Chinese Language Training Center for International Students. Since the early 1990s, it has recruited international students from all over the world, focusing on the recruitment of ASEAN students.

In addition to regular teaching, the school received an average of 945.4 language learners and short-term students targeting language learning and cultural experience in the past five years (2013-2017), most of which were from ASEAN

The construction of teaching platform for ASEAN students is not only the performance on student scale, but also on the setting of courses and the construction of teaching materials. For instance, in the undergraduate training program in the direction of "Chinese language literature" and "business Chinese", a compulsory course for Chinese and foreign translation and Chinese to foreign interpretation are opened for the juniors and the seniors. The college will arrange the translation and interpretation courses according to the students' nationalities, thus offering the translation and interpretation courses in ASEAN languages.

In 2009, in collaboration with the Guangxi Normal University Press, this university published a series of Chinese language textbooks specially for ASEAN students, namely "Charming Chinese", which includes 6 books, covering all levels from zero level higher level(A1-C2).

\section{B. Mode 2: Management Platforms Targeting ASEAN Students}

On the basis implementing national laws and regulations, the university established full-blown rules and regulations for international student management, and standardized the process of international students' enrollment, teaching and daily management. The rules and regulations cover all kinds of international students, such as undergraduate students, master's students, doctoral students and language students. They are involved in international enrollment, daily management, teaching management, degree management, education, and so on. In June 2017, the international exchange department compiled the rules and regulations, offering them to international student management staff and leaders and instructors concerned, with a view to guiding the international student administration.

ASEAN students are the main source of enrollments. In addition to the Chinese version, a number of rules and regulations from the International Exchange Office of the university are also available in English, Indonesian, Vietnamese, Thai, and other languages that can be recognized by international students from ASEAN. Meanwhile, in order to facilitate the management of ASEAN students, the professional background of the management staff of the International Exchange Department includes talents specializing in Vietnamese, Indonesian and Thai 
languages, including foreign teachers from ASEAN , Working as assistants to the ASEAN-related educational programs.

\section{Mode 3: Campus Construction Platforms Targeting ASEAN Students}

College campus culture is multi-dimensional. It is "not only expressed in ideological-political education, moral \& legal education, professional education, but in the campus environment as well, including the planning of cultural landscapes, the display of multiculturalism, the integration of foreign culture into their own campus culture, making foreign students have a sense of intimacy and belonging, broadening students' visions minds.[4]

The material and cultural aspects of campus culture "are usually presented in the form of campus environments and equipment settings, and they are external manifestations of the materialization of school development" [5]. Guangxi Normal University is also embodying the ASEAN feature in terms of campus environment construction. It embodies the organic integration of multiculturalism in the campus landscape. The school has sculptures embodying the SinoVietnamese people's friendship. There are Vietnam School Memorial Halls displaying educational relics and commemorative photos of Vietnam Southern Schools. There are also Thai Cultural Center, Indonesian Cultural Center, Dance Rehearsal Room for ASEAN International Students Rehearsal Venue.

\section{Mode 4: Cultural Activity Platforms Targeting ASEAN Students}

Guangxi Normal University provided diverse cultural activity platforms for ASEAN students, many of which have had a major impact in Guangxi and even the whole country.

They have caused a wide range of media coverage from universities, Guilin local media, Guangxi media, other provincial media and national media.

In mid-April each year, the school organizes an international cultural festival of the ASEAN theme. The festival includes a series of sub-projects, such as the Thai Songkran Festival, on which, Thai students, together with students from Laos, Cambodia, Myanmar and other countries get together to celebrate the New Year in their cultures. There are also Indonesian Culture Day and other activities. This series of activities is undertaken by ASEAN student unions, with certain support in terms of venues, equipment, and funds from the university.

From 2007, each year in mid-June, the school holds an international student parent conference cum graduation ceremony, inviting parents of international students who are about to graduate to participate. Due to geographical reasons, most parents come from ASEAN countries. The purpose of this parent-teacher association is to enable parents of foreign students to better understand children's learning and living conditions in this university, to strengthen home-school connections, to give full play to the active role of parents, and coordinate with the university sectors in the sense of the educating and managing international students, establishing a good reputation for internationalized education.

In every November, the Vietnamese Culture Day is held at the university. The college provides funding and venue support, and the Vietnamese student association undertakes this activity. Chinese and foreign teachers and students are to be invited to participate in these activities, providing a colorful stage for Vietnamese culture.

From November to December each year, Guangxi Normal University organizes regular activities of exotic cultural experience camps. The main purpose of this experience camp is to allow students from all over the world to show cultures of their home countries in various forms, to experience exotic feelings, and to learn more about foreign cultures.

In addition, this university organizes various crosscultural exchange activities every year. The Chinese and foreign students' union leaders are responsible for the planning, implementation, and feedback of the activities. Whereas, the management staff and teachers only provide guiding opinions and suggestions. This practice can give full play to the conscious activity and innovation of students, but also create a strong Chinese and foreign cultural integration atmosphere, so that the natural blend of ASEAN cultures and Chinese culture becomes a moving part of campus culture in Guangxi Normal University.

\section{E. Mode 5: Cultural Activity Platforms Targeting ASEAN Students}

In the course of teachers' professional development, "teachers form societies in teaching and scientific research, and the formation of organized teaching and scientific research has a positive impact on promoting students' learning and promoting the construction of campus culture" [6]. Teachers and researchers from several colleges and departments in Guangxi Normal University have collaborated in various fields, forming multiple resultant forces in the field of ASEAN Studies. The university has always attached great importance to ASEAN research, and there are several provincial and departmental research centers closely related to ASEAN Studies, such as the Center for China ASEAN History and Reality Research, the Pan Beibu Gulf Regional Research Center, the Vietnam Research Center, the ASEAN Education Research Center, the ASEAN Education Research Center and the ASEAN Women and Children Development Research in Guangxi, and the Institute of ASEAN Education. Relying on these research centers, the university has established many ASEAN-related research teams, such as the Beibu Gulf History and Culture Research Team, the Pan Beibu Gulf Development Research Team, the Pan Beibu Gulf Cooperation Research Team, the Research Team on China ASEAN Legal Systems and International Relations, the Vietnam Research Team, and so on.

Over the years, the school has actively carried out scientific research in various areas of ASEAN. The subjects cover various fields concerning politics, economy, education, law, art and culture, which have achieved fruitful 
accomplishments. At present, "Guangxi Normal University has obtained nearly 100 scientific research projects at all levels for ASEAN, with a total funding of nearly 10 million yuan. More than 100 related books have been published, and a series of more influential research results have caused widespread concern in the academic community. "[1].

\section{F. Mode 6: Discipline Construction Platforms Targeting ASEAN Students}

In order to better serve the national "The Belt and Road Initiative", relying on the long history and deep foundation of education and cultural exchanges between the university and ASEAN countries, in January 2017, "Innovation and Entrepreneurship College of Guangxi Normal University/China-ASEAN Innovation and Entrepreneurship College" was unveiled. And high-tech business incubator park for the students was officially opened.

The "China-ASEAN Innovation and Entrepreneurship Institute" established by the school serves to serve the national "The Belt and Road Initiative" and further promote the establishment of a "sharing economy" ecosystem with ASEAN countries, thus promoting the in-depth cooperation in terms of science \&technology and culture between Guangxi and ASEAN countries, creating an international education brand of innovation and entrepreneurship for students, and to building a demonstration base for innovation and entrepreneurship education for international students in China [7]. The establishment of the college is a contribution to the construction of entrepreneurship education and an important platform for ASEAN students' cultural construction.

\section{CONCLUSION}

To sum up, the related colleges of Guangxi Normal University have achieved outstanding results in building the campus culture targeting ASEAN students in recent years. The campus cultural construction is presented on multimodal platforms covering the material, institutional and spiritual aspects of campus culture, embodied in various modes and platforms concerning teaching, management, and campus construction, cultural activities for international student, scientific research and disciplinary construction.

\section{REFERENCES}

[1] Sun Min. Guangxi Normal University ASEAN Educational Exchange and Cooperation Achievements Exhibition. Guilin Daily, 2014-527:02

[2] Jia Xiaoyan. Exploring the Construction of College Campus Culture. Shijiazhuang: Hebei People's Publishing House, 2015.

[3] Deng Heqiu. Research on the Construction of Campus Culture in Colleges and Universities [M]. Harbin: Heilongjiang People's Publishing House, 2008.

[4] Zheng Yisheng. 2008 China-ASEAN Cultural Forum: An Overview of the Symposium on Campus Culture Construction for International Cooperation[J].Around Southeast Asia, 2008(12):89-90

[5] $\mathrm{Xi}$ Shen. Academic Culture and Campus Culture of Universities.Higher Education Studies, 2012, 2(2):61-65.
[6] DuFour, R. What is a "professional learning community"? Educational Leadership, 2004, 61(8), 6-11.

[7] College of Innovation and Entrepreneurship of Guangxi Normal University. "Innovation and Entrepreneurship College of Guangxi Normal University / China-ASEAN Innovation and Entrepreneurship College"

established.http://cxcy.gxnu.edu.cn/news/zuixinxinwen/2017/0108/10 5.html,2017-01-08. 